\title{
Technological Development and Its Impact on Student Reception of a Campus Radio
}

\author{
Shafizan Mohamed ${ }^{1}$, Saodah Wok $^{1} \&$ Mahaman Lahabou ${ }^{1}$ \\ ${ }^{1}$ Department of Communication, International Islamic University Malaysia, Gombak, Malaysia \\ Correspondence: Shafizan Mohamed, Department of Communication, International Islamic University Malaysia, \\ Gombak, Malaysia. E-mail: shafizan@iium.edu.my
}

Received: September 13, 2017

Accepted: September 30, 2017 Online Published: October 11, 2017

doi:10.5539/jel.v7n1p103

URL: https://doi.org/10.5539/jel.v7n1p103

\begin{abstract}
In 2011, a study was conducted to look at students' reception of IIUM.FM, a newly launched online campus radio. Using the Technological Acceptance Model (TAM), the study found that factors such as perceived ease of use, perceived usefulness, and attitude highly influenced audience reception of the online radio. In 2016, a corresponding study, closely based on the original 2011 study was conducted to chart and identify how technological changes and developments have further affected the radio listeners today and whether the factors that determined listenership in 2011 still apply in 2016. The study employed a quantitative research design using the survey method and the questionnaire as the research instrument. A total of 238 respondents were sampled for 2011 and 271 respondents for 2016. Results from the comparisons done between the two studies identified the impact of technological change on the campus radio and offered recommendations and suggestions to the University's relevant authorities for further improvement.
\end{abstract}

Keywords: audience reception, campus radio, social media, students, IIUM.FM, Technology Acceptance Model (TAM), and cohort study

\section{Introduction}

IIUM.FM is the online campus radio for the International Islamic University Malaysia (IIUM). Founded on $19^{\text {th }}$ April 2010, the radio broadcasts 24 hours a day, 7 days a week worldwide via the Internet. The station is run by the students to inform the campus community, the public and IIUM alumni around the world regarding the university's activities, and current issues from the academic and Islamic perspectives.

Under the supervision of lecturers and staff members in the Department of Communication, Kulliyyah of Islamic Revealed Knowledge and Human Sciences (KIRKHS), students have ample opportunities to apply their theoretical knowledge of the field easily with a well-equipped radio station with digital mixing consoles, high-quality audio equipment, and production rooms.

IIUM.FM is the bridge that links IIUM and the outside world. The English language is used as the medium of interaction instead of other languages in different slots such as Arabic, Mandarin, and Malay languages. In the studio, activities include around the clock positive and meaningful music, religious sermons and talks, and interviews with prominent personalities. Outside the studio, IIUM.FM heavily covers University and Student Union events while also reporting on major news events.

\subsection{The Purpose of IIUM.FM}

The primary purpose of IIUM.FM is to serve as an instructional laboratory for the Department of Communication at the International Islamic University Malaysia (IIUM). The station provides an online broadcast service in the form of information and entertainment programming designed to meet the public interest of the university and surrounding communities. The station is responsible to the Kulliyyah of Islamic Revealed Knowledge (KIRKHS) for the day-to-day operation of the broadcast facility. IIUM.FM is also answerable to the Malaysian Communications and Multimedia Commission (MCMC) for compliance with all laws, rules, and regulations pursuant to the operation of the station.

To date, IIUM.FM has developed a highly successful entertainment format that balances intellectual, spiritual and musical components. The radio playlist includes music, Public Service Announcements (PSA), motivational capsules, religious sermons and Quranic recitations. The format of the radio was developed following a number 
of surveys done by the students as well as insights from the academic fellows. The programming elements used by the students during their air shifts are applicable to a wide range of formats used throughout commercial radio industry. This has enabled the students to attain professional positions at stations using such diverse formats as Islamic, adult contemporary and news/talk.

In addition to music, IIUM.FM hosts many credible talk programs that cover issues that range from the personal to the public as well as the local to the international. Prominent speakers from within and outside the campus are invited to share their thoughts and opinions on issues that affect not only the students but the community as well. The station also airs news updates twice a day, sourcing news from different news providers in an attempt to provide a more objective and an all-encompassing news and information.

\subsection{Challenges of Technological Advancement}

In the seven years that IIUM.FM has operated, it has gone through tremendous technological change and development. When it first operated in 2010, the radio operated in a classroom with minimal equipment. Although it was online, transmission and reception were restricted by the lack of equipment and Internet connection. A new fully functional radio station was built in May 2011. The studio boasts professional radio equipment and facilities that allowed the radio to have quality production and transmission. While production was active, audience reception of the radio was still slow mainly because the campus Internet connection was slow and unable to support mass radio streaming.

While the studio provided the best equipment, it was not susceptible to the rapid changes of Internet technologies. By 2015, the radio transmission was affected by the slow demise of the "Microsoft Media System" which it uses. The Microsoft system was not dynamic and therefore was not compatible in the new media environment that works on many platforms such as Firefox, Chrome, and Android. Because of these systems issue, the radio can only be streamed via Microsoft's Internet browser that is Internet Explorer. This was a major issue as Internet Explorer was no longer popular with the masses. At the same time, the Microsoft system does not support mobile technology. As such, IIUM.FM streaming was limited to laptops and computers only. The radio cannot be heard via mobile devices. This is a major setback as most internet users are now mobile and are more dependent on their Smartphones and mobile devices. A radio application is the most effective and efficient method for online radio as it is fast, simple, mobile and interactive.

With the help of technology experts from the University such as students and lecturers from the Faculty of Engineering and the Information and Technology Division, IIUM.FM managed to overcome the system's issue by replacing the Microsoft system with open source technologies that would allow the system to be more flexible and compatible with rapid technological changes. As a result, by mid-2016, the radio successfully streamed via all Internet browsers. IIUM.FM is also now available in the form of an application via play store. To date, the IIUMFM app is only available for Android users. The budget constraint has restricted it from being available on the Apple platform. The radio app now has more than 500 downloads and has 4.8-star ratings.

IIUM.FM is also very prominent on social media. It has almost 5000 followers on Facebook, 3000 followers on Instagram, 1400 followers on Twitter and 300 subscribers on YouTube. In 2017, the radio started shifting its focus to video by operating via Facebook and YouTube live.

\section{Problem Statement}

The introduction above depicts the development of IIUM.FM as an online campus radio. The Internet may offer easy access to audiences, but the rapid technological developments often pose major challenges. While IIUM.FM is continuously working on updating its transmission and programming, it also needs to understand how the audiences are changing and responding. Because of this, it is important to identify the impact of technology on audience reception. In 2011, a study was conducted to identify the impact of technology on IIUM.FM radio listenership. Using the dimensions proposed by the Technology Acceptance Model (TAM), the 2011 study showed that listenership is very much influenced by the listener's perceptions of the online radio's ease of use, the usefulness of listening and whether the listeners have a favorable attitude towards online radio. Five years on and with many technological developments later, do these conditions still affect the listeners' reception of IIUM.FM.

Secondly, it is equally important for the radio to look at how far it has gone since the first research was conducted in 2011. Has the new technological changes offered by the radio increased the number of listeners and has it provided a good image for the radio. The radio can only develop further if it knows its own strengths and weaknesses. In addition, this study is also important to test whether the TAM model is still significant in 
understanding technological changes. Most importantly, do TAM model variables still influence the listening habits of the listeners?

\subsection{Objectives of the Study}

In response to the problems identified above, the objectives of the study are:

1) To compare the patterns of listening among listeners of 2016 to 2011 ;

2) To analyze the relationship between knowledge about IIUM.FM, the perceived ease of use, perceived usefulness of listening, attitude towards listening, and the actual listening to IIUM.FM; and

3) To differentiate the mediating effect on the relationship between knowledge and actual listening for 2016 compared to the 2011 reception on the IIUM.FM study.

\subsection{Significance of the Study}

This study is significant in three ways. First and foremost, since it is a longitudinal study on the reception of IIUM.FM, it is mainly significant to inform the campus radio about where it has been since 2010. This study will be able to chart the progress and development of the campus radio while also providing suggestions and recommendations for the betterment of the campus radio. Further actions can be taken by the relevant university authority especially in terms of attracting more listenership, not only focusing on the IIUM students but also to the public at large, locally and internationally.

Second, the study should benefit the radio industry in general especially in this challenging times where radio in its traditional form can no longer satisfy the demands of new media users. Radio now comes in different medium and platform and as such requires rigorous adaptation in terms of programming and transmission. As such this study should be able to inform the industry about the nature of new radio listeners and how to respond to them.

Lastly, as an academic study, this study should add to the understanding of new media technologies by scrutinizing the viability of using the Technological Acceptance Model (TAM) in explaining how TAM variables such as perceived use and perceived usefulness are valid enough to explain technological use.

\section{Literature Review}

\subsection{The Technology Acceptance Model}

Lin (2009) suggests that the adoption of online radio involves many aspects and consideration on the part of users. Among others, it depends on whether they feel comfortable with the new technology or not. The Technology Acceptance Model (TAM) is able to identify this connection. Developed by Davis (1989), TAM assumes that an individual's acceptance of the information system is determined by two major factors: Perceived Ease Of Use (PEOU) and Perceived Usefulness (PU). Classified under the information system theory, TAM examines how users accept and use a computer-based technology. The actual use of the technology is influenced directly and indirectly by user's behavioral intents, attitude, perceived ease of use, and perceived usefulness of the system. External factors can also affect the model. In this study, the external factor is knowledge about the IIUM.FM. The intention to use is not taken into consideration as such variable is asked to the non-listeners. This paper incorporates only the listeners to IIUM.FM.

\subsubsection{Actual Listening Behavior}

Actual listening is reflected by the actual use of the Internet to get connected to the IIUM.FM online radio. The actual use is the outcome of the knowledge of the existence of the campus radio. Such act reflects the process of accessing to the Internet in gaining access the online radio. It is the behavior done by the users of the technology.

\subsubsection{Factors Influencing Actual Listening Behavior}

Knowledge is gained through an exposure to the information of interest to create a sense of understanding about a new thing. It can be done intentionally (actively) and also through unintended action (passively). In the case of IIUM.FM, a student may gain knowledge about it through other students, notice boards, the Internet, announcements, Facebook, WhatsApp and other means. Knowledge alone is not enough especially when pertaining to new technology. Therefore, the technology must be easy to use.

Perceived Ease Of Use (PEOU) in this study is labeled as Perceived Ease Of Listening (PEOL). It refers to "the degree to which a person believes that using a particular system would be free of effort" (Davis, 1989, p. 2). If the IIUM.FM is easily connected to the system and the system is accessible, then the campus radio is encouraging the students to listen to it, effortlessly. This is the driving force of listening to the radio. In addition, the perceived ease of use should be complemented with its usefulness. This call for the next concept that is 
called perceived usefulness and in this study, it is labeled as Perceived Usefulness Of Listening (PUOL). Using Davis' definition, PUOL is defined as "the degree to which a person believes that using a particular system would enhance his or her job performance" (Davis, 1989, p. 2). Therefore, for this study, instead of job performance, it is being replaced by the listening habit.

Attitude plays another aspect in the study. The liking and preference toward a type of information are very important for the actual behavior-listening. Ajzen (1991) defines attitude as "an individual's disposition to react with a certain degree of favorableness or un-favorableness to an object, behavior, person, institution, or event". In terms of technological acceptance in general, it has been found that people's use of the Internet has been related to emotional stability. Hamburger and Ben-Artzi (2000) show that emotional stability is related to the use of many Internet platforms. For men, extraversion is positively related to social use, while neuroticism is negatively related to the use of information services. On the other hand, it is found that for women, extraversion is unfavorably related to social use, while neuroticism is favorably linked to social use. An investigation of how these attitudes are related to feelings of loneliness and Internet use support the notion that attitude affects technology adoption. Similarly, Swickert et al. (2002) find that personal attitude moderates the relationship between computer use and experiences of social support, although the only moderate association is found between personality and computer use. In relation to these findings, attitude drives and forces the person concerned toward performing the act, in this case, the listening to IIUM.FM. This reflects the student's positive liking and positive feeling toward IIUM.FM.

\section{Conceptual Framework}

The conceptual framework of the study is presented in Figure 1.

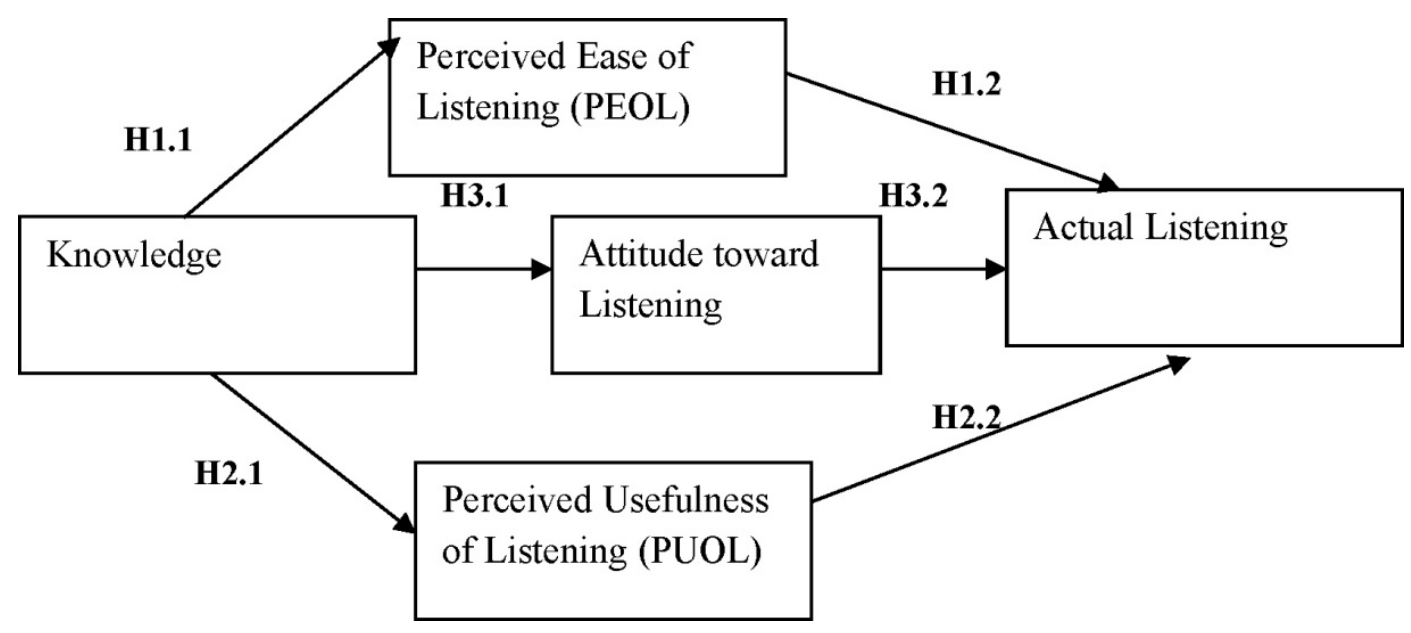

Figure 1. Conceptual framework of the actual listening of IIUM.FM

\subsection{Hypotheses of the Study}

The hypotheses formulated are based on the conceptual framework. They are as follow:

GH1: Knowledge influences Perceived Ease Of Listening (PEOL) which, in turn, influences actual listening.

SH1.1: Knowledge influences Perceived Ease Of Listening (PEOL).

SH1.2: Perceived Ease Of Listening (PEOL) influences actual listening.

GH2: Knowledge influences Perceived Usefulness Of Listening (PUOL) which, in turn, influences actual listening.

SH2.1: Knowledge influences Perceived Usefulness Of Listening (PUOL).

SH2.2: Perceived Usefulness Of Listening (PUOL) influences actual listening.

GH3: Knowledge influences attitude toward listening which, in turn, influences actual listening.

SH3.1: Knowledge influences attitude toward listening. 
SH3.2: Attitude toward listening influences actual listening.

\section{Methodology}

The study uses the quantitative research design where a cross-sectional survey method is used. Similar to the method used in 2011, the present study uses the same questionnaire for data collection.

\subsection{Population and Sampling Procedure}

The population of the study consists mainly of undergraduate students for 2011 and 2016. This is because the IIUM.FM is housed in the Human Sciences Division (HS) of the faculty. HS consists of seven departments. The selection of the HS students is based on the location of the campus radio studio itself. In 2016, the division has about 5000 students, more than the number of student enrolment in 2011, when there were only 2487 students.

The sampling procedure used for the study is the stratified random sampling method. The stratum is based on the department to ensure that each department has its own students selected for the study to avoid biases. Even though the study also takes into consideration the listeners and non-listeners, however, for this paper, only the listeners are analyzed to answer the objectives of the study and to test the formulated hypotheses for the study.

\subsection{Research Instrument}

The same questionnaire that was developed in 2011 is used for the present study (2016). This is used to compare the cohort for the respective year and such cohort is considered a form of a longitudinal study to tap the change that has taken place ever since its inception in 2010. The developed questionnaire was verified by an expert at the Department of Communication who was in-charge of the broadcast studio. The questionnaire consists of nine sections: Section 1 consists of three subsections: (1a) demographic background of the respondents; (1b) computer/laptop ownership with the Internet connection; and (1c) the utilization of IIUM.FM; Section 2: Knowledge about IIUM.FM; Section 3: Perceived usefulness of listening (PUOLP to IIUM.FM; Section 4: Perceived ease of listening (PEOL) to IIUM.FM; Section 5: Attitude towards listening to IIUM.FM; Section 6: Actual listening to IIUM.FM; and Part 7: Comments and suggestions. However, sections 8 and 9 are meant for the non-listeners.

For this study, the variables used are knowledge, Perceived Ease Of Listening (PEOL), Perceived Usefulness Of Listening (PUOL), attitude, and actual listening to IIUM.FM.

Knowledge consists of 10 items measured using a dichotomous option, where 1 is coded for "yes" while 0 is coded for "no". An example of the item asked is "IIUM.FM is accessible only through the Internet". Therefore, the maximum score is 10 while the minimum score is 0 if no correct answer is attained. Perceived ease of listening is measured using 11 items. An example of the PEOL item is "I find it easy to listen to IIUM.FM". Similarly, for PUOL, a total of 11 items is used. An example of PUOL is "Listening to IIUM.FM would foster my sense of belonging to IIUM community". Attitude toward listening to IIUM.FM is also measured using 11 items. An example of the question is that "I like listening to IIUM.FM". PEOL, PUOL and attitude are measured using a 5 -point Likert scale where $1=$ strongly disagree, $2=$ disagree, $3=$ slightly agree, $4=$ agree, and $5=$ strongly agree. The actual listening is composed of 11 items and is measured using a 5-point Likert-like scale, where $1=$ never, $2=$ rarely, $3=$ sometimes, $4=$ often, and $5=$ always.

Results in Table 1 show that all the constructs are reliable for both 2011 and 2016 data where the Cronbach alpha values exceed .70 , as required.

Table 1. Reliability of selected variables

\begin{tabular}{llll}
\hline Variable & No. of Items & Phase 1 $(\mathrm{N}=237)$ & Phase 2 $(\mathrm{N}=267)$ \\
\hline Perceived usefulness of listening & 11 & .93 & .93 \\
Perceived ease of listening & 11 & .93 & .93 \\
Attitude toward listening & 11 & .94 & .95 \\
Actual listening & 11 & .93 & .90 \\
\hline
\end{tabular}

\subsection{Procedure and Data Collection}

The developed questionnaire was pretested to forty undergraduates from Islamic Revealed Knowledge (IRK) Division on 2, 9-13 August 2010. Based on the pre-test, no changes or modifications were made to the 
questionnaire. The first phase of data collection was conducted from 4-7 October and again from 12 December until 10 January 2011 while the second phase took place in November 2016. The questionnaires were distributed at class time with the permission from the lecturers concerned. The researchers approached the lecturers concerned before the class to get their consents, even though a permission letter from the Deputy Dean Academic Affairs had already been obtained. Each listener took about 10 minutes to complete the questionnaire. Such process of data collection is considered as a field study using a survey method. A total of 467 students answered the questionnaires for 2011 while for 2016 a total of 468 . However, only 238 were the listeners to IIUM.FM for 2011 while for 2016, a total of 271 were listeners. There is an increase of 33 listeners. Unfortunately, not all of them answered all the questions.

\subsection{Data Analysis}

The collected data were analyzed using the Statistical Package for Social Sciences (SPSS) version 17. Both descriptive and inferential statistics are used for the study. For the descriptive statistics, frequency, percentage, mean, standard deviation, minimum and maximum values are presented. To test the hypotheses of the study, partial correlation and hierarchical regression analyses were used for the study. The mean differences between the two phases for the respective variables studied are calculated manually by using the following formula:

$$
\mathrm{t}=(\text { Mean } 1-\text { Mean } 2) / \sqrt{ }\left(\mathrm{s}^{2} / \mathrm{N} 1+\mathrm{s} 2^{2} / \mathrm{N} 2\right)
$$

\section{Results}

\subsection{Demographic Characteristics of the Respondents}

There are more listeners in Phase $2(n=271)$ compared to Phase $1(n=238)$. The profile of respondents in Phase 1 and Phase 2 are presented in Table 2. As expected, there are more females than males in both phases of the study. The age category is also similar, with mean about 22 years old, except that the minimum and maximum age for Phase 1 is wider than the Phase 2. The majority of the respondents (above 80\%) in both phases are Malaysians. The distribution of respondents according to the department reveals that there are more listeners from the Department of Communication than the other departments; more so for Phase 2 compared to Phase 1. In contrast, fourth year students participated in Phase 1 while in Phase 2; as there are more second year students. Other than that, the respondents are considered similar in terms of their personal attributes.

Table 2. Profile of the listeners

\begin{tabular}{|c|c|c|c|c|c|}
\hline \multirow[t]{2}{*}{ Respondents Profile } & \multirow[t]{2}{*}{ Category } & \multicolumn{2}{|c|}{ Phase 1} & \multicolumn{2}{|l|}{ Phase 2} \\
\hline & & Frequency & Percentage & Frequency & Percentage \\
\hline \multirow[t]{3}{*}{ Gender } & Male & 65 & 27.3 & 98 & 36.2 \\
\hline & Female & 173 & 72.7 & 173 & 63.8 \\
\hline & Total & 238 & 100.0 & 271 & 100.0 \\
\hline \multirow[t]{6}{*}{ Age group (years) } & $18-21$ years old & 63 & 26.5 & 101 & 37.3 \\
\hline & 22 years old and above & 175 & 73.5 & 170 & 62.7 \\
\hline & Total & 238 & 100.0 & 271 & 100.0 \\
\hline & & Mean=21.78, & & Mean $=22.00, \mathrm{SD}=1.39$ & \\
\hline & & $\mathrm{SD}=1.91$ & & $\operatorname{Min}=20, \operatorname{Max}=29$ & \\
\hline & & $\operatorname{Min}=18, \operatorname{Max}=37$ & & & \\
\hline \multirow[t]{3}{*}{ Nationality } & Malaysian & 200 & 84.0 & 226 & 83.4 \\
\hline & International & 38 & 16.0 & 45 & 16.6 \\
\hline & Total & 238 & 100.0 & 271 & 100.0 \\
\hline \multirow[t]{3}{*}{ Department } & COMM & 87 & 36.6 & 174 & 64.2 \\
\hline & DELL & 24 & 10.1 & 15 & 5.5 \\
\hline & HIST & 18 & 7.6 & 16 & 5.9 \\
\hline
\end{tabular}




\begin{tabular}{|c|c|c|c|c|c|}
\hline & PSCI & 30 & 12.6 & 13 & 4.8 \\
\hline & PSYC & 41 & 17.2 & 24 & 8.9 \\
\hline & SOCA & 36 & 15.1 & 7 & 2.6 \\
\hline & Others & 2 & 0.8 & 22 & 8.1 \\
\hline & Total & 238 & 100.0 & 271 & 100.0 \\
\hline \multirow[t]{5}{*}{ Level of study (year) } & First & 22 & 9.2 & 34 & 12.5 \\
\hline & Second & 52 & 21.8 & 109 & 40.2 \\
\hline & Third & 62 & 26.1 & 76 & 28.1 \\
\hline & Fourth & 102 & 42.9 & 52 & 19.2 \\
\hline & Total & 238 & 100.0 & 271 & 100.0 \\
\hline
\end{tabular}

\subsection{Patterns of Listening to IIUM.FM}

Table 3 presents the patterns of listening to IIUM.FM, the campus radio. More than half of the number of respondents in both phases (Phase $1=51.9 \%$ and Phase $2=55.7 \%$ ) have the experience of listening to IIUM.FM for quite some time, that is, more than a month ago. This means that IIUM.FM existence has been known by the campus student community. Similarly, they spend mainly between 11-30 minutes per session (Phase 1 for $44.4 \%$ and Phase 2 for $46.0 \%$ ). The listeners spend more time in Phase 1 (mean=32.10 minutes) compared to Phase 2 (mean=26.34 minutes). Nonetheless, the minimum and the maximum time spent are about the same. The frequency of listening per week can be classified as mainly on a 1-day basis per week for both phases of the study (Phase 1 for $52.4 \%$ and Phase of $49.8 \%$ ). Even though the majority of Phase 2 respondents listen to IIUM.FM at the hostels (student accommodation), many of them in Phase 1 also listen to IIUM.FM at their hostel. In terms of listening time, about half the number of respondents listen to it at night (Phase 1 of $50.6 \%$ and Phase 2 of 49.4\%), mainly after a hard day's academic work at the faculty. Probably, they need the relaxation and most of them listen to music $(84.8 \%$ for Phase 1 and $55.4 \%$ for Phase 2). In addition, $51.7 \%$ of Phase 2 respondents also listen to talk shows. The majority of Phase 2 respondents $(84.5 \%)$ indicate that they listen to IIUM.FM because it is considered new for them since most of them are in their second year while only $66.2 \%$ in Phase 1 respondents think that it is new as most of the listeners are in their fourth year.

Table 3. Patterns of listening to IIUM.FM

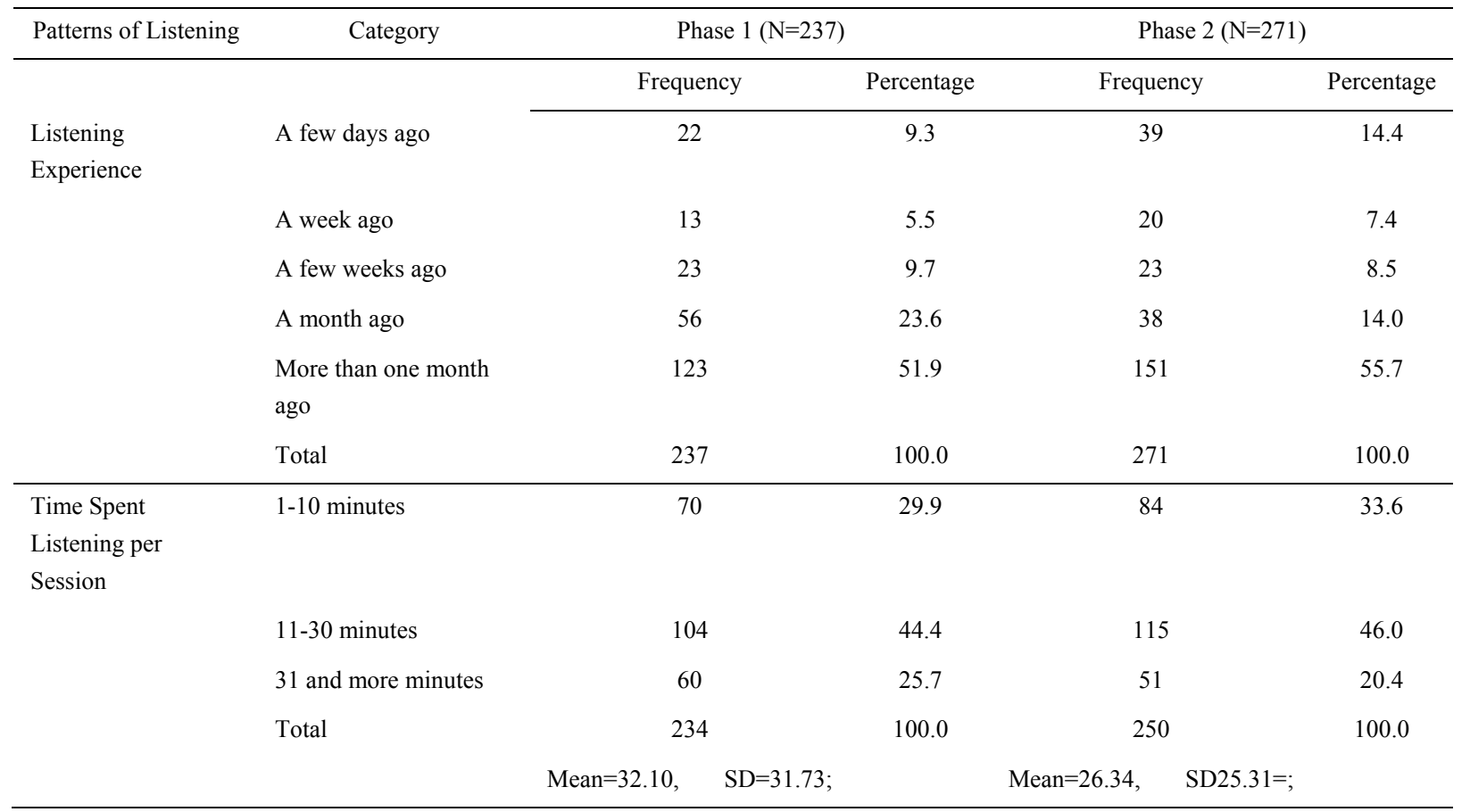


$\operatorname{Min}=1, \operatorname{Max}=190 \mathrm{~min}$

Min=1, Max=200 $\min$

\begin{tabular}{|c|c|c|c|c|c|}
\hline \multirow{5}{*}{$\begin{array}{l}\text { Frequency of } \\
\text { Listening per Week }\end{array}$} & 1 day & 121 & 52.4 & 132 & 49.8 \\
\hline & 2 days & 41 & 17.7 & 66 & 24.9 \\
\hline & 3 days & 38 & 16.5 & 44 & 16.6 \\
\hline & 4 and more days & 31 & 13.4 & 23 & 8.7 \\
\hline & Total & 231 & 100.0 & 265 & 100.0 \\
\hline \multirow[t]{7}{*}{ Place of Listening } & Mahallah & 131 & 55.5 & 229 & 84.5 \\
\hline & Home & 59 & 25.0 & 11 & 4.1 \\
\hline & IIUM PC Lab & 17 & 7.2 & 12 & 4.4 \\
\hline & Canteen/Café & 14 & 5.9 & 6 & 2.2 \\
\hline & Library & 9 & 3.8 & - & - \\
\hline & $\begin{array}{l}\text { Others (e.g., not } \\
\text { specific place) }\end{array}$ & 6 & 2.5 & 10 & 3.7 \\
\hline & Total & 236 & 100.0 & $*$ & $*$ \\
\hline \multirow[t]{6}{*}{ Time of Listening* } & Night & 120 & 50.6 & 134 & 49.4 \\
\hline & Evening & 77 & 32.5 & 74 & 27.3 \\
\hline & Afternoon & 46 & 19.4 & 48 & 17.7 \\
\hline & Morning & 34 & 14.3 & 36 & 13.3 \\
\hline & $\begin{array}{l}\text { Others (e.g., no specific } \\
\text { time) }\end{array}$ & 28 & 11.8 & 22 & 8.1 \\
\hline & Total $(\mathrm{N}=237)$ & $*$ & $*$ & $*$ & $*$ \\
\hline \multirow{8}{*}{$\begin{array}{l}\text { Programs Listened } \\
\text { to* }\end{array}$} & Music & 201 & 84.8 & 150 & 55.4 \\
\hline & News & 62 & 26.2 & 73 & 26.9 \\
\hline & $\begin{array}{l}\text { Public service } \\
\text { announcements }\end{array}$ & 56 & 23.6 & 49 & 18.1 \\
\hline & Talk shows & 47 & 19.8 & 140 & 51.7 \\
\hline & Religious programs & 41 & 17.3 & 55 & 20.3 \\
\hline & Weather forecast & 9 & 3.8 & 4 & 1.5 \\
\hline & $\begin{array}{l}\text { Others (e.g., nothing } \\
\text { specific) }\end{array}$ & 0 & 0 & 6 & 2.2 \\
\hline & Total $(\mathrm{N}=237)$ & * & $*$ & $*$ & $*$ \\
\hline \multirow{5}{*}{$\begin{array}{l}\text { Reasons for } \\
\text { Listening* }\end{array}$} & Because it's new & 157 & 66.2 & 125 & 84.5 \\
\hline & $\begin{array}{l}\text { To get more music } \\
\text { variety }\end{array}$ & 71 & 30.0 & 97 & 4.1 \\
\hline & For its religious content & 34 & 14.3 & 69 & 4.4 \\
\hline & $\begin{array}{l}\text { Other (e.g., to fill my } \\
\text { leisure time) }\end{array}$ & 19 & 8.0 & 64 & 2.2 \\
\hline & Total $(\mathrm{N}=237)$ & * & * & $*$ & * \\
\hline
\end{tabular}

\footnotetext{
*Multiple responses.
} 


\subsection{Mean Comparisons between Phases 1 and 2 Results}

The variables used for the study include knowledge, PEOL, PUOL, attitude and actual listening. The differences between the respective variables are manually calculated based on the mean differences divided by the standard error of each pair of the corresponding variable. Results (Table 4) show that there are differences between knowledge for Phase 1 and Phase 2 of the study, where listeners in Phase 1 are more knowledgeable than those in Phase $2(t=2.531, p<.05)$. Since IIUM.FM was established in 2010 , there is a possibility that some of the questions are easy to remember as IIUM.FM has just been established. It is also found that attitude toward IIUM.FM in Phase 1 is less than that in Phase $2(t=-4.698, p<.05)$. The negative attitude of those listeners in Phase 1 can be due to the novelty of the campus radio and many students do have a positive liking and preference for its content. Other variables: PEOL, PUOL and actual listening are not found to be different between Phase 1 and Phase 2. Hence, there are similarities between Phase 1 and Phase 2 in terms of easiness, usefulness and the actual listening of IIUM.FM. Nonetheless, actually listening is classified as negative-"sometimes" for both phases. Hence, there is still room for improvement. Therefore, it is suggested that more publicity and promotional campaign be carried out intensively especially to the IIUM campus community as a whole. As it is, the number of non-listeners in Phase 1 is 229 while the number of non-listeners in Phase 2 is 197 students.

Table 4. Mean and standard deviation for selected variables

\begin{tabular}{|c|c|c|c|c|c|c|c|c|}
\hline \multirow[t]{2}{*}{ Variable } & \multicolumn{3}{|c|}{ Phase $1(\mathrm{~N} 1=237)$} & \multicolumn{3}{|c|}{ Phase $2(\mathrm{~N} 2=267)$} & \multirow[t]{2}{*}{$t$} & \multirow[t]{2}{*}{$p$} \\
\hline & Mean & SD & $\%$ & Mean & $\mathrm{SD}$ & $\%$ & & \\
\hline Knowledge & 8.50 & 1.66 & 85.0 & 8.15 & 1.42 & 81.5 & 2.531 & $<.05$ \\
\hline PEOL & 3.25 & 0.99 & 65.0 & 3.31 & 0.67 & 66.2 & -0.788 & $>.05$ \\
\hline PUOL & 3.24 & 0.98 & 64.8 & 3.36 & 0.67 & 67.2 & -1.587 & $>.05$ \\
\hline Attitude & 2.98 & 0.88 & 59.6 & 3.31 & 0.67 & 66.2 & -4.698 & $<.05$ \\
\hline Actual listening & 2.77 & 1.05 & 55.4 & 2.68 & 0.68 & 53.6 & 1.128 & $>.05$ \\
\hline
\end{tabular}

Critical value of $1.96, \mathrm{p}=.05$.

\subsection{Hypotheses Testing for 2016 Study}

6.4.1 GH1: Knowledge Influences Perceived Ease of Listening (PEOL) Which, in Turn, Influences Actual Listening

In order to test the mediating effect of Perceived Ease Of Listening (PEOL), the correlation among the variables must be significant. Such criteria are met (Table 5) where knowledge and actual listening are positively correlated with actual listening $(r=.248, p=.000)$ even though the relationship is rather weak, yet it is significant. The relationship between knowledge and the mediating variable (PEOL) is also significantly correlated $(r=.191$, $p=.001)$ despite the fact that the relationship is weak positive. Above all, the relationship between PEOL and actual listening is significantly positive $(r=.588, p=.000)$. Therefore, H1.1 and H1.2 are supported and the mediating effect has been performed. Results show that PEOL is able to mediate the relationship between knowledge and actual listening with a reduction of correlation value from $r=.248$ to $r=.171$. Therefore, GH1 is partially supported. These results are further found to be in line with the results in Table 6 , where the Beta of .248 $(t=4.167, p=.000)$ in Model 1 has been reduced to Beta of .141 $(t=2.814, p=.005)$ which is also significant despite the fact that there is the reduction in the Beta value.

Table 5. Zero and partial correlation among knowledge, perceived ease of listening and actual listening

\begin{tabular}{llrrrcc}
\hline \multicolumn{1}{c}{ Control Variable } & \multicolumn{1}{c}{ Variable } & $\mathrm{N}$ & Mean & SD & Listening & Knowledge \\
\hline None & Actual listening & 267 & 2.683 & 0.678 & 1 & 1 \\
& Knowledge & 267 & 8.154 & 1.423 & $r=.248, p=.000$ & $r=.191, p=.001$ \\
\multirow{3}{*}{ PEOL } & PEOL & 267 & 3.313 & 0.667 & $r=.588, p=.000$ & 1 \\
& Actual listening & 267 & 2.683 & 0.678 & 1 & 1 \\
\hline
\end{tabular}


Table 6. Hierarchical regression analysis for testing the mediating effect of PEOL

\begin{tabular}{|c|c|c|c|c|c|c|}
\hline \multirow[t]{2}{*}{ Model } & \multirow[t]{2}{*}{ Variable } & \multicolumn{2}{|c|}{ Unstandardized Coefficients } & \multirow{2}{*}{$\begin{array}{l}\text { Standardized } \\
\text { Coefficients } \\
\text { Beta }\end{array}$} & \multirow[t]{2}{*}{$T$} & \multirow[t]{2}{*}{$p$} \\
\hline & & $\mathrm{B}$ & SE & & & \\
\hline \multirow[t]{2}{*}{1} & Constant & 1.719 & .235 & & 7.322 & .000 \\
\hline & Knowledge & .118 & .028 & .248 & 4.167 & .000 \\
\hline \multicolumn{7}{|c|}{$\mathrm{F}=17.362, \mathrm{df}=1,265, p=.000 ; \mathrm{R}=.248, \mathrm{R}^{2=} \cdot 061, \mathrm{R}^{2} \mathrm{Adj}=.058$} \\
\hline \multicolumn{7}{|c|}{$\mathrm{R}^{2}$ Change $=.061, \mathrm{~F}$ Change $=17.362, \mathrm{df}=1,265, p=.000$} \\
\hline \multirow[t]{3}{*}{2} & Constant & .246 & .234 & & 1.050 & .295 \\
\hline & Knowledge & .067 & .024 & .141 & 2.814 & .005 \\
\hline & PEOL & .571 & .051 & .561 & 11.217 & .000 \\
\hline \multicolumn{7}{|c|}{$\mathrm{F}=75.683, \mathrm{df}=2,264, p=.000 ; \mathrm{R}=.604, \mathrm{R}^{2}=.364, \mathrm{R}^{2} \mathrm{Adj}=.360$} \\
\hline \multicolumn{7}{|c|}{$\mathrm{R}^{2}$ Change $=.303, \mathrm{~F}$ Change $=125.826, \mathrm{df}=1,264, p=.000$} \\
\hline
\end{tabular}

6.4.2 GH2: Knowledge Influences Perceived Usefulness Of Listening (PUOL) Which, in Turn, Influences Actual Listening

The criteria for performing the mediating effect are met where all the correlations among knowledge, PUOL and actual listening are found to be significant (Table 7). Specifically, knowledge is significantly correlated with actual listening $(r=.247, p=.000)$, with PUOL $(r=.204, p=.000)$, although the relationships are weak and yet they are significant. PUOL is moderately correlated with actual listening $(r=.584, p=.000)$. Therefore, both sub-hypotheses (SH2.1 and SH2.2) are supported. In addition, Table 8 shows that Beta value of .247 for knowledge in Model 1 has been reduced to Beta of .134. However, both results are significant $(t=4.145, p=.000)$ in Model 1 and is reduced to $t=2.651(p=.009)$ in Model 2. Therefore, GH2 is partially supported because PUOL is unable to reduce the relationship significantly. This implies that PUOL partially mediates the relationship between knowledge and actual listening.

Table 7. Zero and partial correlation among knowledge, perceived usefulness of listening and actual listening

\begin{tabular}{llrrrcc}
\hline \multicolumn{1}{c}{ Control Variable } & \multicolumn{1}{c}{ Variable } & $\mathrm{N}$ & Mean & $\mathrm{SD}$ & Listening & Knowledge \\
\hline None & Actual listening & 266 & 2.682 & 0.679 & 1 & 1 \\
& Knowledge & 266 & 8.150 & 1.424 & $r=.247, p=.000$ & $r=.204, p=.000$ \\
& PUOL & 266 & 3.356 & 0.667 & $r=.584, p=.000$ & 1 \\
PUOL & Actual listening & 266 & 2.682 & 0.679 & 1 & 1 \\
& Knowledge & 266 & 8.150 & 1.424 & $r=.161, p=.004$ & \\
\hline
\end{tabular}

Table 8. Hierarchical regression analysis for testing the mediating effect of PUOL

\begin{tabular}{|c|c|c|c|c|c|c|}
\hline \multirow[t]{2}{*}{ Model } & \multirow[t]{2}{*}{ Variable } & \multicolumn{2}{|c|}{ Unstandardized Coefficients } & \multirow{2}{*}{$\begin{array}{l}\text { Standardized } \\
\text { Coefficients } \\
\text { Beta }\end{array}$} & \multirow[t]{2}{*}{$t$} & \multirow[t]{2}{*}{$p$} \\
\hline & & $\mathrm{B}$ & SE & & & \\
\hline \multirow[t]{2}{*}{1} & Constant & 1.721 & .235 & & 7.315 & .000 \\
\hline & Knowledge & .118 & .028 & .247 & 4.145 & .000 \\
\hline \multicolumn{7}{|c|}{$\mathrm{F}=17.180, \mathrm{df}=1,264, p=.000 ; \mathrm{R}=.247, \mathrm{R}^{2}=.061, \mathrm{R}^{2} \mathrm{Adj}=.058$} \\
\hline \multicolumn{7}{|c|}{$\mathrm{R}^{2}$ Change $=.061, \mathrm{~F}$ Change $=17.180, \mathrm{df}=1,264, p=.000$} \\
\hline \multirow[t]{2}{*}{2} & Constant & .259 & .236 & & 1.098 & .273 \\
\hline & Knowledge & .064 & .024 & .134 & 2.651 & .009 \\
\hline
\end{tabular}


PUOL

.567

.051

11.039

.000

$\mathrm{F}=73.447, \mathrm{df}=2,263, p=.000 ; \mathrm{R}=.599, \mathrm{R}^{2}=.358, \mathrm{R}^{2} \mathrm{Adj} .=353$;

$\mathrm{R}^{2}$ Change $=.297, \mathrm{~F}$ Change $=121.849, \mathrm{df}=1,263, p=.000$.

\subsubsection{GH3: Knowledge Influences Attitude toward Listening Which, in Turn, Influences Actual Listening}

Table 9 reveals that attitude is able to mediate the relationship between knowledge and actual listening with attitude as the mediating effect whereby the correlation value has been reduced from $r=.248$ ( $p=.000)$ to $r=.202$ $(p=.003)$. This is because all the relationships among the variables are significant and this allows the mediating effect analysis to be conducted as the criteria for performing such analyses are permissible. This means that SH3.1 and SH3.2 are supported. However, GH 3 is partially supported. The results are further confirmed (Table $10)$ as there is a reduction in Beta value of $.657(p=.000)$ to Beta $.485(p=.000)$, giving a reduction $3 \%$ explained the variance.

Table 9. Zero and partial correlation among knowledge, attitude and actual listening

\begin{tabular}{lllllcc}
\hline Control Variable & \multicolumn{1}{c}{ Variable } & $\mathrm{N}$ & Mean & SD & Listening & Knowledge \\
\hline None & Actual listening & 267 & 2.683 & 0.678 & 1 & 1 \\
& Knowledge & 267 & 8.154 & 1.423 & $r=.248, p=.000$ & $r=.149, p=.008$ \\
\multirow{3}{*}{ Attitude } & Attitude & 267 & 3.313 & 0.667 & $r=.658, p=.000$ & 1 \\
& Actual listening & 267 & 2.683 & 0.678 & 1 & 1 \\
\hline
\end{tabular}

Table 10. Hierarchical regression analysis for testing the mediating effect of attitude

\begin{tabular}{|c|c|c|c|c|c|c|}
\hline \multirow[t]{2}{*}{ Model } & \multirow[t]{2}{*}{ Variable } & \multicolumn{2}{|c|}{ Unstandardized Coefficients } & \multirow{2}{*}{$\begin{array}{l}\text { Standardized } \\
\text { Coefficients } \\
\text { Beta }\end{array}$} & \multirow[t]{2}{*}{$T$} & \multirow[t]{2}{*}{$p$} \\
\hline & & B & SE & & & \\
\hline \multirow[t]{2}{*}{1} & Constant & .743 & .140 & & 5.296 & .000 \\
\hline & Knowledge & .625 & .044 & .657 & 14.176 & .000 \\
\hline \multicolumn{7}{|c|}{$\mathrm{F}=200.966, \mathrm{df}=1,264, p=.000 ; \mathrm{R}=.657, \mathrm{R}^{2}=.432, \mathrm{R}^{2} \mathrm{Adj}=.430$} \\
\hline \multicolumn{7}{|c|}{$\mathrm{R}^{2}$ Change $=.432, \mathrm{~F}$ Change $=200.966, \mathrm{df}=1,264, p=.000$} \\
\hline \multirow[t]{3}{*}{2} & Constant & .397 & .161 & & 2.456 & .015 \\
\hline & Knowledge & .461 & .059 & .485 & 7.802 & .000 \\
\hline & Attitude & .254 & .063 & .250 & 4.017 & .000 \\
\hline \multicolumn{7}{|c|}{$\mathrm{F}=114.311, \mathrm{df}=2,263, p=.000 ; \mathrm{R}=.682, \mathrm{R}^{2}=.465, \mathrm{R}^{2} \mathrm{Adj}=.461$} \\
\hline \multicolumn{7}{|c|}{$\mathrm{R}^{2}$ Change $=.033, \mathrm{~F}$ Change $=16.134, \mathrm{df}=1,263, p=.000$} \\
\hline
\end{tabular}

\subsection{Hypotheses Testing for 2011 Study}

The zero-order correlations among the variables are presented in Table 11. Results show that all the relationships among the variables are significantly positive. Thus, all the criteria for performing the mediating effects are met. The findings of Phase 1 show that PEOL, PUOL, and attitude are able to partially mediate the relationships between knowledge on actual listening (Table 12). These results coincide with the present study of Phase 2016. Hence, it can be concluded that the results of Phase 1 are similar to the results of Phase 2. 
Table 11. Zero-order correlations among the selected variables for Phase 1 (2011)

\begin{tabular}{lllcc}
\hline Variables & Actual Listening & Knowledge & PEOL & PUOL \\
\hline Actual listening & \multicolumn{1}{c}{1} & & \\
Knowledge & $r=.319, p=.000$ & 1 & & \\
PEOL & $r=.575, p=.000$ & $r=.326, p=.000$ & & 1 \\
PUOL & $r=.631, p=.000$ & $r=.262, p=.000$ & $r=.595, p=.000$ & $r=.796, p=.000$ \\
Attitude & $r=.692, p=.000$ & $r=.180, p=.006$ & $r=.6644, p=.000$ & $r$ \\
\hline
\end{tabular}

Source: Lahabou, M. (2011). Human Science students' acceptance of IIUM.FM: A test of the Technology Acceptance Model.

Table 12. Summary of regression results for 2011 study

\begin{tabular}{|c|c|c|c|}
\hline Control Variable & Variables & Beta & $P$ \\
\hline \multirow[t]{2}{*}{ None } & Knowledge & .319 & .000 \\
\hline & PEOL & .575 & .000 \\
\hline PEOL & Knowledge & .142 & .013 \\
\hline \multicolumn{4}{|l|}{$\mathrm{F}=62.203, \mathrm{df}=2,223, p=.000 ; \mathrm{R}^{2}=0.358$} \\
\hline \multirow[t]{2}{*}{ None } & Knowledge & .319 & .000 \\
\hline & PUOL & .631 & .000 \\
\hline PUOL & Knowledge & .153 & .004 \\
\hline \multicolumn{4}{|l|}{$\mathrm{F}=85.831, \mathrm{df}=2,221, p=.000 ; \mathrm{R}^{2}=0.437$} \\
\hline \multirow[t]{2}{*}{ None } & Knowledge & .319 & .000 \\
\hline & Attitude & .692 & .000 \\
\hline Attitude & Knowledge & .191 & .000 \\
\hline $\mathrm{F}=118.683, \mathrm{df}=2,223, p=.000 ; \mathrm{R}^{2}=0.516$ & & & \\
\hline
\end{tabular}

\section{Discussion and Conclusion}

From the results above, the study finds that a number of non-listeners exists for both Phase 1 (2011) and Phase 2 (2016). This calls for a major drive to encourage students to listen to IIUM.FM. Publicity and the promotional announcement should be aggressively done to encourage more listenership.

In addition, the study reveals that there are more similarities between the Phase 1 and Phase 2 results. In fact, they complement each other. Therefore, all the variables used in the TAM model are accepted and it holds true for the study at both phases. This is because both findings reveal similar outcomes pertaining to the relationships and the mediating effects of PEOL, PUOL and attitude. However, other variables need to be considered such as the student learning culture and their free time. As such, the study has been able to verify that the TAM model is still very much viable to study the relationship between radio listenership and technological acceptance.

In a nutshell, when considering only the listenership, the acceptance of IIUM.FM does not experience a significant change from 2011. As such, more effort must be taken to ensure that consistent increase in listenership is achieved. While it has been stated that there are other important indicators such as the social media reach that should be considered, listenership is evidently the main business for radio. As such, IIUM.FM needs to take all actions, either in the form of promotion or a new method of programming. Students involved in the radio must be trained to understand that technological advancement highly impact listenership and as such, they need to always be alert and informed of new technological updates.

\section{Limitations and Suggestions}

One of the shortcomings of the study is that it does not consider the views of non-listeners. As such, it is advised that other research especially coming from the bodies that govern the radio to identify the reasons for non-listenership. 
Another shortcoming is that the study is not able to address the significance of social media followers. Today's media ratings not only include actual numbers of listenership but also the numbers of followers on the social media. This is because, in commercial radio, social media ratings are also used to attract advertisers (Bonini \& Monclús, 2014). Social media followers are also informed about the radio's content and programming as they are constantly updated via the social media. As such, while the number of listeners of IIUM.FM does not indicate the major increase from 2011, IIUM.FM managed to gather a significant number of followers on the social media which was non-existent 6 years ago. Therefore, in future, the study should address more than just listenership but also consider radio exposure and reception via the social media. A new model of measuring radio reception that goes beyond listenership will also help the radio industry in general to understand the new patterns in the relationship between audiences and technological change.

\section{References}

Ajzen, I. (1991). The theory of planned behavior. Organizational Behavior and Human Decision Processes, 50(1), 179-211. https://doi.org/10.1016/0749-5978(91)90020-T

Bonini, T., \& Monclús, B. (Eds.). (2014). Radio audiences and participation in the age of network society (Vol. 6). New York, NY: Routledge.

Davis, F. D. (1989). Perceived usefulness, perceived ease of use, and user acceptance of information technology. MIS Quarterly, 13(3), 319-340. https://doi.org/10.2307/249008

Hamburger, Y. A., \& Ben-Artzi, E. (2000). The relationship between extraversion and neuroticism and the different uses of the Internet. Computers in Human Behavior, 16(4), 441-449. https://doi.org/10.1016/S0747-5632(00)00017-0

Lahabou, M. (2011). Human Science students' acceptance of IIUM.FM: A test of the Technology Acceptance Model (Unpublished Master Thesis). International Islamic University Malaysia (IIUM).

Lin, C. A. (2009). Exploring the online radio adoption decision-making process: Cognition, attitude, and technology fluidity. Journalism \& Mass Communication Quarterly, 86(4), 884-899. https://doi.org/10.1177/107769900908600410

Malmi, E., \& Weber, I. (2016, February). You are what apps you use: Demographic prediction based on user's apps (pp. 635-638). Available from ICWSM.

Svendsen, G. B., Johnsen, J. A. K., Almås-Sørensen, L., \& Vittersø, J. (2013). Personality and technology acceptance: The influence of personality factors on the core constructs of the Technology Acceptance Model. Behaviour \& Information Technology, 32(4), 323-334. https://doi.org/10.1080/0144929X.2011.553740

Swickert, R. J., Hittner, J. B., Harris, J. L., \& Herring, J. A. (2002). Relationships among Internet use, personality, and social support. Computers in Human Behavior, 18(4), 437-451. https://doi.org/10.1016/S0747-5632(01)00054-1

Xu, Q., Erman, J., Gerber, A., Mao, Z., Pang, J., \& Venkataraman, S. (2011, November). Identifying diverse usage behaviors of Smartphone apps. In Proceedings of the 2011 ACM SIGCOMM conference on Internet measurement conference (pp. 329-344). ACM. https://doi.org/10.1145/2068816.2068847

\section{Copyrights}

Copyright for this article is retained by the author(s), with first publication rights granted to the journal.

This is an open-access article distributed under the terms and conditions of the Creative Commons Attribution license (http://creativecommons.org/licenses/by/4.0/). 